\title{
Analisis dan Perancangan Sistem Informasi Produksi Pada UMKM Kerupuk Sidoarjo
}

\author{
Endah Asmawati \\ Jurusan Teknik Informatika Jurusan Teknik Informatika \\ Universitas Surabaya \\ endah@staff.ubaya.ac.id \\ hiani@staff.ubaya.ac.id
}

a

\author{
Arif Herlambang \\ Jurusan Manajemen \\ Universitas Surabaya \\ arif_herlambang@staff.uba \\ ya.ac.id
}

\author{
Yon Haryono \\ Jurusan Teknik Manufaktur \\ Universitas Surabaya \\ y_haryono@staff.ubaya.ac.
} id

\begin{abstract}
Abstrak - Usaha Mikro Kecil dan Menengah (UMKM) merupakah salah satu unit usaha yang berperan cukup penting pada sektor perekonomian Indonesia. Banyaknya UMKM yang tetap eksis meskipun perekonomian nasional sedang lesu membuat UMKM menjadi unit bisnis yang dapat mengurangi pengangguran. Penelitian ini bertujuan untuk mengetahui permasalahan UMKM dalam melakukan pencatatan adminstrasi. Untuk itu dilakukan pendekatan kualitatif dengan mengambil sampel sebanyak 12 UMKM yang memproduksi kerupuk mentah di Kecamatan Krembung. Teknik pengumpulan data menggunakan metode wawancara terstruktur. Berdasarkan hasil wawancara diketahui bahwa sebagian UMKM tidak melakukan pencatatan administrasi dengan baik, sehingga UMKM sering keliru pada proses produksi. UMKM berkeinginan untuk dapat melakukan pencatatan adminstrasi yang baik. Untuk itu dirancang sistem informasi produksi yang dapat dapat menyimpan data konsumen, dapat mencatat pesanan sekaligus melakukan pengecekan kemampuan produksi untuk pesanan tersebut. Selain itu dengan sistem yang baru pemilik dapat mengetahui jadwal produksi sesuai tanggal pengambilan, mengetahui stok barang (kerupuk) dan bahan baku, melihat detail pemesan (nama, asal daerah, tanggal pemesanan, tanggal pengambilan, jenis dan jumlah kerupuk), dan jumlah kelebihan kerupuk. Dengan sistem ini UMKM dapat melihat status pembayaran, apakah pelanggan sudah membayar lunas atau kurang bayar, jika kurang bayar akan terlihat berapa kekurangan yang harus dibayar pelanggan.

Kata Kunci : UMKM, Kerupuk, Administrasi, Sistem Informasi Produksi
\end{abstract}

\section{PENDAHULUAN}

Usaha Mikro Kecil dan Menengah (UMKM) merupakan salah satu sektor perekonomian yang tetap eksis meskipun perekonomian nasional sedang lesu. Hal ini terbukti saat terjadi krisis ekonomi 1998, dimana banyak perusahaan yang harus gulung tikar namun tidak sedikit UMKM yang masih tetap bisa bertahan [1]. Di Indonesia, Sidoarjo merupakan kabupaten yang mempunyai banyak UMKM, baik UMKM yang memproduksi pangan ataupun non pangan. Pemerintah daerah Sidoarjo sangat perhatian terhadap UMKM yang ada di daerahnya. Informasi pembinaan UMKM sering dilakukan oleh pemerintah Kabupaten Sidoarjo melalui dinas terkait yang bertujuan membantu para UMKM untuk bisa survive dalam menghadapi membanjirnya produk luar negeri dengan harga dan kualitas yang kompetitif. Salah satu hasil produksi UMKM yang terkenal dari Sidoarjo adalah kerupuk.

Meskipun UMKM menjadi bagian penting dari perekonomian Indonesia, namun tidak sedikit UMKM yang masih kesulitan dalam pencatatan administrasi dan keuangan. Dari beberapa penelitian sebelumnya menunjukkan bahwa sebagian besar UMKM tidak melakukan pencatatan dengan baik [2], ada sedikit yang melakukan pembukuan sederhana namun ternyata pembukuan tersebut belum bisa membantu UMKM untuk mendapatkan informasi mengenai stok barang, bahan baku atau laba rugi UMKM [3]. Atau dengan kata lain, pembukuan sederhana yang dilakukan masih banyak kekurangan. Hal yang sama juga terjadi pada UMKM kerupuk di Kecamatan Krembung. Hampir semua UMKM tidak melakukan pencatatan administrasi dengan baik.

Salah satu cara yang dapat dilakukan untuk meningkatkan daya saing dan produktivitas UMKM adalah dengan meningkatkan pengetahuan teknologi UMKM. Pengetahuan ini terdiri atas peralatan fisik, kemampuan sumber daya manusia, sistem informasi, dan kelembagaan/ kepemimpinan [4].

Berdasarkan karakteristik dari UMKM dalam hal pencatatan administrasi, maka salah satu cara yang dapat dilakukan adalah merancang sebuah sistem informasi produksi yang dapat membantu administrasi UMKM. Adminstrasi yang dimaksud meliputi pencatatan pesanan, penjadwalan waktu dan jumlah produksi, pencatatan stok barang dan bahan baku, serta mengetahui status pembayaraan.

\section{METODOLOGI PENELITIAN}

Langkah awal penelitian ini adalah mencari informasi jumlah UMKM kerupuk di kecamatan Krembung. UMKM yang menjadi sampel penelitian dipilih berdasarkan beberapa kriteria, (1) mempunyai omzet lebih dari 200 juta perbulan. 
Omzet dijadikan kriteria utama karena tingkat kompleksitas pembukuannya lebih banyak dibandingkan yang omzetnya kecil. (2) Pencatatan administrasi dilakukan pemilik langsung. Pemilik yang merangkap sebagai tenaga administrasi mempunyai peluang besar untuk melakukan kesalahan dalam mengambil keputusan untuk proses produksi. Berdasarkan kriteria di atas, diperoleh 12 UMKM yang memenuhi. Kemudian, kepada 12 UMKM ini, dilakukan ini wawancara terstruktur. Wawancara berisi 3 topik yaitu kondisi pencatatan saat ini, kelebihan dan kelemahan sistem yang ada, harapan sistem yang baru. Hasil wawancara dianalisis sehingga diperoleh pokok permasalahan yang ada di UMKM. Kemudian dari analisis ini dirancang sistem informasi yang dapat membantu menyelesaikan permasalahan UMKM. Pada proses perancangan difokuskan pada 2 UMKM yang mempunyai karakteristik proses produksi yang hampir sama. Perancangan sistem informasi produksi dilakukan dengan membuat Entity Relationship Diagram (ERD) dan desain tampilan muka. Berikut ini merupakan beberapa pengertian yang digunakan pada tulisan ini.

\section{A. Sistem Informasi Produksi}

Sistem Informasi Produksi merupakan sistem informasi manajemen yang menyediakan informasi tentang kegiatan yang terkait dengan perencanaan dan pengendalian proses untuk memproduksi barang atau jasa. Sistem informasi produksi terdiri dari 2 macam, pertama sistem produksi fisik, yaitu berbagai kegiatan yang mengarahkan pada proses produksi yang bertujuan untuk membuat suatu sistem yang menghasilkan biaya minimal dan waktu yang cepat. Dua elemen utama adalah order control dan follow control. Jenis kedua adalah sistem informasi produksi yang mendukung semua aktifitas produksi untuk menghasilkan barang atau jasa [5].

\section{B. Entity Relationship Diagram (ERD)}

ERD adalah suatu model untuk menjelaskan hubungan antar data dalam basis data berdasarkan objek-objek dasar data yang mempunyai hubungan antar relasi. Tahapan pertama pada desain sistem informasi menggunakan ERD adalah menggambarkan kebutuhan informasi atau jenis informasi yang akan disimpan dalam database. Tahap berikutnya adalah desain logis, dimana data dipetakan ke model logis, seperti model relasional. Model logis ini kemudian dipetakan menjadi model fisik [6]. Secara umum metodologi ERD adalah sebagai berikut:

1. Menentukan entitas. Entitas adalah segala sesuatu yang dapat digambarkan oleh data, juga dapat diartikan sebagai individu yang mewakili sesuatu nyata dan dapat dibedakan dari sesuatu yang lain (Fathansyah,1999). Pada langkah ini akan ditentukan semua hal dimana pengguna menyimpan data.

2. Menentukan relasi, yaitu hubungan antar pasangan entitas menggunakan matriks relasi

3. Gambar ERD sementara. Entitas digambarkan kotak dan relasi digambarkan dengan garis
4. Isi kardinalitas. Kardinalitas menunjukkan jumlah entitas yang dapat berelasi dengan entitas lain, yang terdiri dari satu ke satu, satu ke banyak, dan banyak ke banyak.

5. Tentukan kunci utama, yaitu menentukan atribut (pendeskripsian karakteristik dari entitas) yang mendidentifikasi satu dan hanya satu kejadian setiap entitas

6. Gambar ERD berdasarkan kunci. Pada langkah ini relasi banyak ke banyak dihilangkan dan memasukkan primary dan kunci pada setiap entitas

7. Menentukan atribut

8. Pemetaan atribut, memasangkan atribut dengan entitas yang sesuai

9. Gambar ERD dengan atribut, yaitu mengatur ERD dengan menambahkan entitas yang ditemukan

10. Periksa hasil.

\section{HASIL DAN PEMBAHASAN}

Berdasarkan kondisi yang dijelaskan pada pendahuluan, maka dilakukan analisis dan perancangan sistem untuk menyelesaikan permasalahan UMKM. Langkah awal dalam menyelesaikan permasalahan adalah dengan melakukan analisa kondisi saat ini, yaitu kondisi sistem yang saat ini digunakan oleh UMKM. Untuk lebih fokus pada penyelesaian permasalahan, maka analisis dilakukan pada dua UMKM yang mempunyai karakteristik yang hampir sama. Selanjutnya akan dijelaskan langkah-langkah yang digunakan untuk menyelesaikan permasalahan UMKM dalam bentuk diagram proses produksi dan dilanjutkan desain data base sistem serta desain tampilan.

\section{A. Analisa Kondisi Saat ini}

UMKM yang menjadi rekanan adalah dua UMKM yang memproduksi kerupuk mentah. Setiap hari jumlah tepung yang digunakan untuk memproduksi kerupuk berkisar antara 1,6 - 2 ton, dimana $1000 \mathrm{~kg}$ tepung akan menghasilkan 1025 kg kerupuk. Saat ini, semua aktivitas produksi dilakukan sesuai perintah dari pemilik, mulai dari menerima pesanan, belanja bahan baku, perencanaan produksi, pelaksanaan produksi, keuangan dan pembukuan. Proses administrasi (keuangan dan pembukuan) tidak dilakukan secara tertib, sehingga pemilik tidak bisa menghitung keuntungan atau kerugian yang dialami dalam satu kali proses produksi. Biasanya keuntungan dihitung hanya dari selisih jumlah kerupuk yang dihasilkan dengan jumlah tepung yang digunakan, tanpa memperhatikan faktor-faktor lain. Produksi kerupuk dilakukan saat ada pesanan (biasanya melalui telepon), kemudian hasil produksi akan diambil oleh pemesan. Jadi UMKM tidak memikirkan biaya pengiriman.

Saat ada pesanan, pemilik tidak pernah menolak pesanan tersebut, padahal ada batas maksimal pada kapasitas produksinya. Hal ini menyebabkan pemilik seringkali mengambil produk UMKM lain untuk memenuhi pesanan. Kondisi seperti ini rawan akan keberlanjutan pesanan, karena ada kemungkinan kualitas kerupuknya berbeda. Salah satu penyebab pemilik tidak menolak pesanan karena pemilik 
merasa masih mampu untuk memenuhi pesanan tersebut, padahal pesanan sudah melebihi kapasitas produksi harian. Mereka tidak memiliki daftar pesanan sesuai dengan hari pengambilan. Pencatatan pesanan hanya dilakukan pada sebuah nota dan cara penyimpanan nota juga tidak terlalu tertib. Pemilik tidak memiliki catatan urutan produksi sesuai hari pengambilan kerupuk. Sehingga pernah terjadi kerupuk $\mathrm{X}$ yang seharusnya untuk pelanggan dari Jakarta diberikan ke pelanggan dari Bandung. Saat pelanggan dari Jakarta akan mengambil pesanannya, pemilik baru ingat kalau hari itu pesanannya akan diambil. Hal seperti ini tentu akan merugikan bagi pelanggan baik dari sisi waktu ataupun biaya.

Pada saat pelanggan memesan melalui telepon, maka pelanggan akan membayar (transfer) minimal setengah dari total harga. Jika uang sudah diterima pemilik, maka pemilik akan merencakan produksinya. Kekurangan pembayaran akan diberikan saat pelanggan mengambil barang. Saat ini informasi tersebut hanya ditulis pada nota yang rawan hilang dan mengandalkan ingatan pemilik. Untuk mengatasi kesalahan ingatan maka perlu dibuat sistem yang bisa menginformasikan status pembayaran dan sisa yang harus dibayar.

Berdasarkan kondisi di atas, maka akan dirancang sebuah sistem yang mempunyai karakteristik: (1) mencatat pesanan sekaligus melakukan pengecekan kemampuan produksi untuk pesanan tersebut, (2) dengan pencatatan ini,UMKM akan mempunyai data pelanggan, (3) perencanaan produksi yang lebih baik, karena dengan sistem yang baru pemilik dapat mengetahui jadwal produksi sesuai tanggal pengambilan, mengetahui stok bahan baku dan kerupuk, melihat detail pemesan (nama, asal daerah, tanggal pemesanan, tanggal pengambilan, jenis dan jumlah kerupuk), dan jumlah kelebihan kerupuk, (4) dapat melihat status pembayaran, apakah pelanggan sudah membayar lunas atau kurang bayar, jika kurang bayar akan terlihat berapa kekurangan yang harus dibayar pelanggan.

\section{B. Diagram Proses Produksi}

Pada diagram proses produksi dijelaskan bagaimana proses pada sistem informasi yang dibuat dapat menjawab permasalahan. Rancangan sistem meliputi penerimaan pesanan, pembuatan nota jual sampai proses pengambilan produk. Secara rinci proses produksi dapat dilihat pada diagram di Gambar 1.

Pada sistem yang dirancang, saat ada pesanan maka akan dilakukan perhitungan estimasi waktu produksi dan kesediaan bahan baku. Pada saat melakukan estimasi produksi, sistem akan menunjukkan daftar tunggu produksi sesuai dengan tanggal pengambilan barang. Apabila memungkinkan untuk waktu produksi dan bahan baku maka dibuat nota jual. Saat pembuatan nota jual, akan dicek apakah barang pesanan ada di gudang atau tidak, jika ada maka pembeli dapat langsung melakukan transaksi pembelian. Biasanya pembelian langsung terjadi untuk pelanggan yang datang langsung ke rumah produksi dan membeli dalam jumlah sedikit. Sedangkan jika barangnya tidak tersedia maka pemilik melakukan perencanaan produksi yaitu memastikan bahan baku tersedia 1 hari sebelum produksi dan pesanan sanggup untuk dipenuhi berdasarkan maksimal kapasitas produksi. Apabila bahan baku kurang maka pemilik akan menambah stok bahan baku dengan cara menelepon agen. Biasanya hari itu juga agen akan mengirimkan bahan baku tersebut, paling lambat satu hari kemudian. Langkah selanjutnya dibuat nota produksi. Satu nota produksi digunakan untuk produksi satu jenis kerupuk setiap pesanan. Informasi yang dicatat di nota produksi meliputi identitas pemesan, jenis dan jumlah kerupuk, estimasi tanggal mulai dan selesai produksi, status bahan baku, dan informasi realisasinya. Dengan pencatatan ini, pemilik memiliki data pelanggan. Setelah semua siap, maka proses produksi dilakukan.

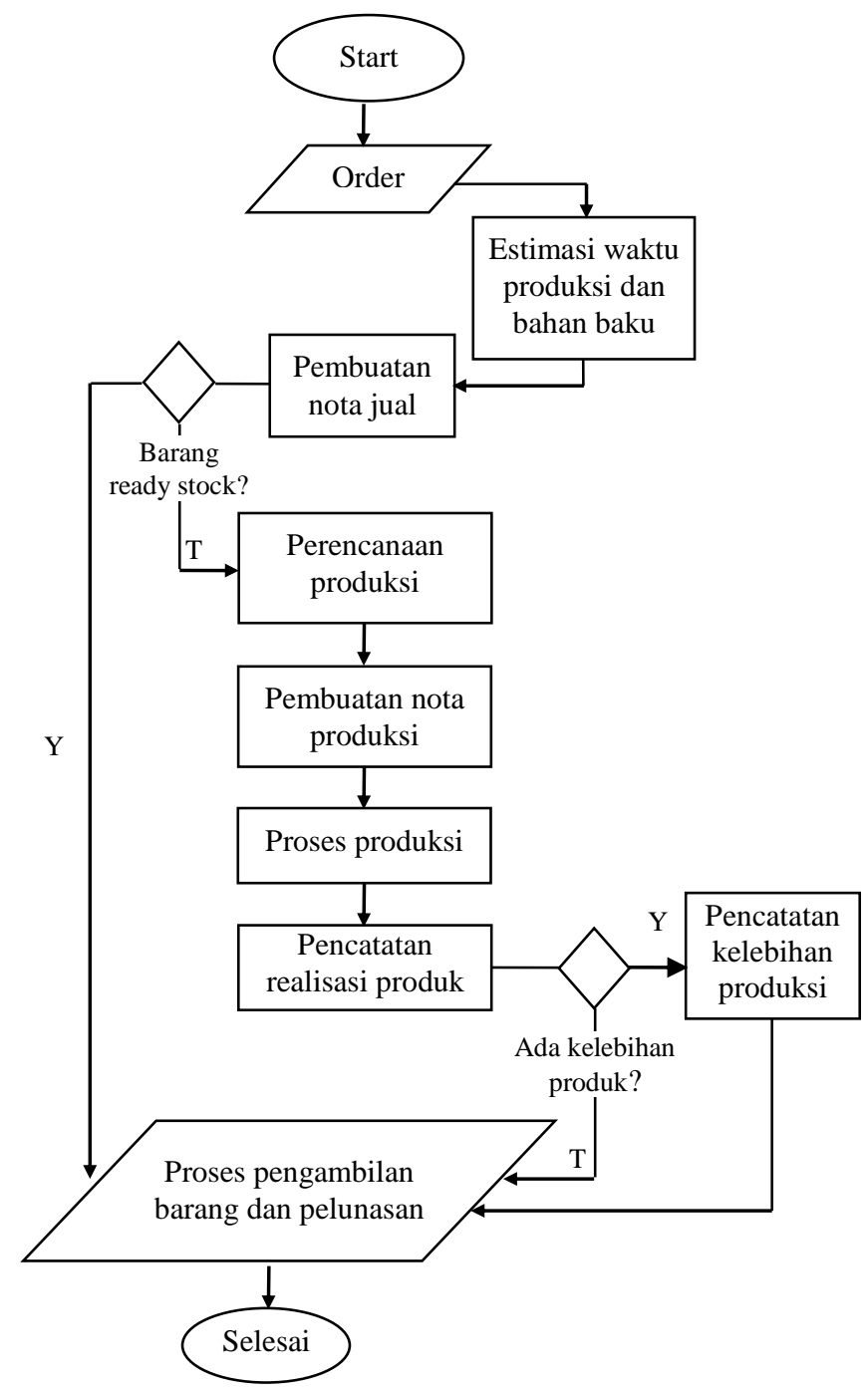

Gambar 1. Diagram Proses

Proses produksi kerupuk dimulai dengan pencampuran semua bahan (tepung, bawang/ikan, penyedap, pewarna makanan (jika diperlukan), garam) dengan air hangat. Proses pencampuran ini dilanjutkan dengan memasukkan adonan pada sebuah mesin pengaduk. Setelah semua bahan 
tercampur sempurna, adonan mulai dicetak, dan dilanjutkan pada proses mematangkan adonan. Proses memasak adonan dilakukan di sebuah oven dalam waktu 5-15 menit, tergantung pada jenis kerupuknya. Pada beberapa jenis kerupuk, setelah matang maka kerupuk tersebut harus diangin-anginkan terlebih dahulu sebelum dikeringkan. Proses pengeringan kerupuk dilakukan pada sebuah mesin pengering. Proses pengeringan ini yang memerlukan waktu cukup lama, sekitar $4-6$ jam untuk kerupuk sejumlah $600-$ 800 kuintal. Proses pengeringan merupakan proses terakhir pada proses produksi kerupuk. Proses paling akhir adalah mengemas kerupuk dalam wadah plastic $5 \mathrm{~kg}$. Setelah semua proses produksi selesai, maka dilakukan pencatatan realisasi produk. Jika ada kelebihan jumlah kerupuk dari produksi maka dilakukan pencatatan sehingga stok kerupuk akan tercatat. Dengan tercatatnya stok kerupuk ini, maka pemilik dapat memutuskan apakah kerupuk bisa dijual saat ada pembeli yang datang langsung ke tempat produksi. Dengan pencatatan ini UMKM dapat memutuskan secara langsung ketersediaan produk, tanpa khawatir produk tersebut merupakan pesanan orang lain.

\section{Entity Relationship Diagram}

Berdasarkan analisis kebutuhan sistem dan dari diagram proses yang di buat, maka dibuat ERD yang mewakili kondisi tersebut. Gambar 2 memperlihatkan ER Diagram yang dideskripsikan Crows Foot, yang terdiri dari 10 tabel.

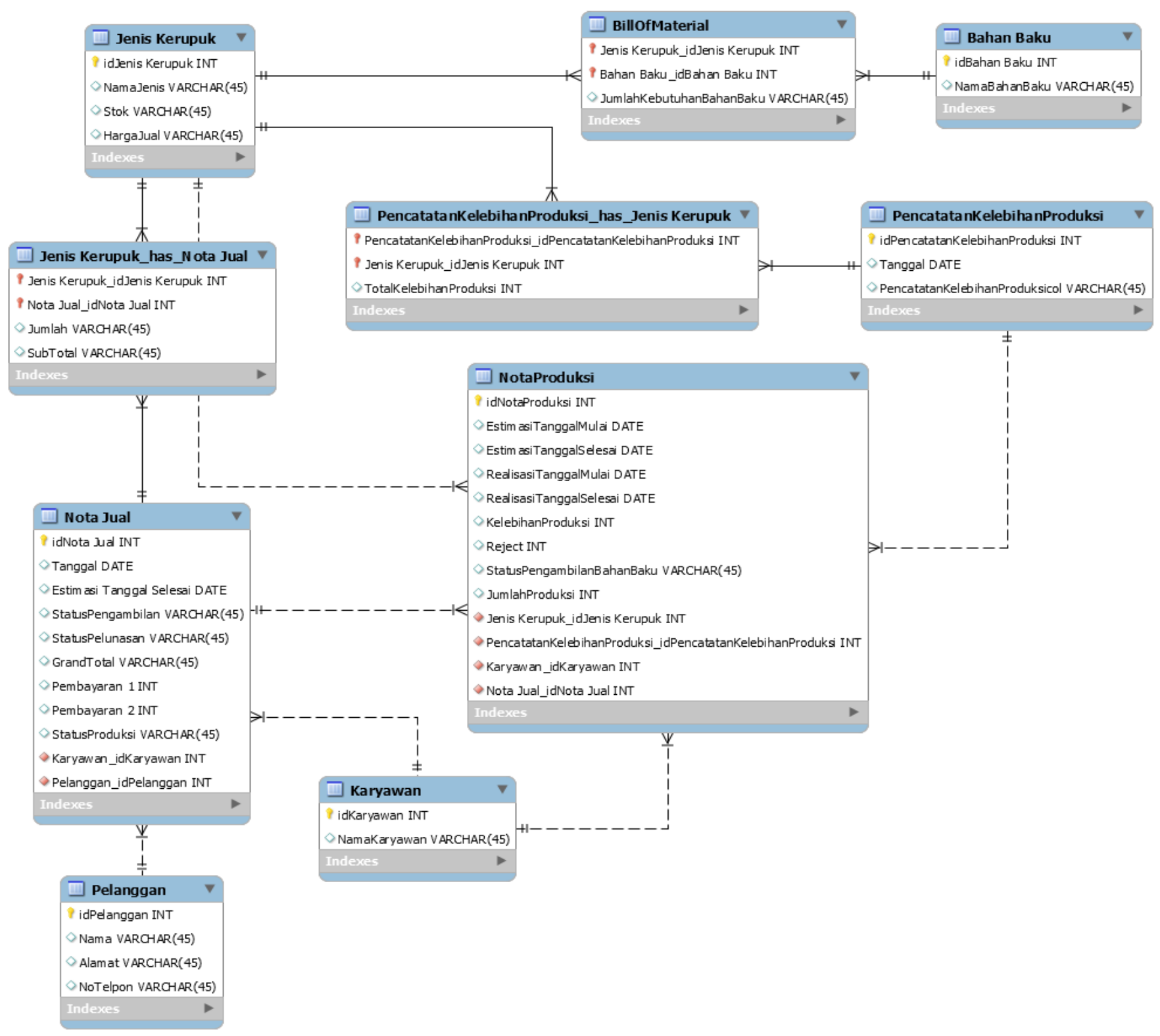

Gambar 2. ER Diagram Sistem Informasi Produksi Kerupuk 


\section{Desain Tampilan}

Sebelum rancangan sistem informasi produksi diimplementasikan maka terlebih dahulu dibuat desain untuk tampilan antar muka. Rancangan tampilan antar muka dibuat dengan memperhatikan latar belakang dari UMKM. Kedua pemilik UMKM yang menjadi mitra penelitian ini memiliki keterbatasan dalam mengoperasikan handphone. Smartphone yang dipunyai hanya digunakan untuk menelepon, dan kadang-kadang untuk membaca pesan. Fitur-fitur yang ada di handphone belum digunakan secara maksimal. Saat ditanya tentang kemauannya untuk lebih memanfaatkan fitur di handphone, mereka bersedia selama ada yang mau mengajari.

Antar muka yang diterapkan untuk sistem ini adalah antar muka berbasis mobile application, yaitu dirancang untuk dapat diakses melalui ponsel berbasis Android dengan layar sentuh berukuran 5 hingga 6 inchi. Pertimbangan pemilihan ini berdasarkan analisa kebutuhan pengguna, yaitu pemilik UMKM memerlukan pencatatan segera atas proses produksinya, tetapi mereka tidak memiliki waktu yang cukup untuk dapat mencatatnya dengan baik menggunakan perangkat komputer desktop maupun laptop. Hampir sepanjang hari, pemilik UMKM berada pada lokasi produksi atau di lapangan, sehingga akan lebih memudahkan apabila pencatatan dapat dilakukan secara langsung, menggunakan perangkat bergerak yaitu smartphone atau PC tablet. Selain itu ukuran smartphone 4-6 inchi dapat memudahkan pemilik untuk dimasukkannya ke saku, dan layar tersebut cukup besar untuk dapat menampilkan transaksi dan laporan.

Antar muka dibuat sesederhana mungkin untuk memudahkan pemilik dalam mengoperasikannya. Contoh rancangan antar muka untuk nota produksi dapat dilihat pada Gambar 3, dimana sebagian besar mereka hanya memilih dari pilihan yang disediakan, hanya beberapa saja yang harus mengisi secara manual.

Desain yang sudah dirancang dievaluasi dengan cara ditunjukkan ke kedua UMKM. Kedua UMKM diminta untuk memberikan penilaian ke rancangan sistem yang baru. Berdasarkan hasil penilaiannya, kedua UMKM berpendapat sama bahwa: (1) sistem yang baru dapat mencatat pesanan dan melakukan pengecekan kemampuan produksi untuk pesanan tersebut, (2) dengan sistem yang baru pemilik dapat mengetahui jadwal produksi sesuai tanggal pengambilan, mengetahui stok bahan baku dan kerupuk, melihat detail pemesan (nama, asal daerah, tanggal pemesanan, tanggal pengambilan, jenis dan jumlah kerupuk), dan jumlah kelebihan kerupuk, (3) dapat melihat status pembayaran (lunas atau kurang bayar), jika kurang bayar akan terlihat berapa kekurangan yang harus dibayar pelanggan, (2) data pelanggan akan tersimpan di database system, sehingga UMKM mempunyai data pelanggan,

\begin{tabular}{|c|c|c|}
\hline \multicolumn{3}{|c|}{ NOTA PRODUKSI } \\
\hline PERENCANAAN & & \\
\hline Nomor Nota Produksi & : & \\
\hline Nomor Nota Jual & $:[$ & \\
\hline ID Pelanggan & : [ID] / [Nam & \\
\hline ID Karyawan & $:[$ & [nama karyawan] \\
\hline Jenis Kerupuk & $:$ & [nama kerupuk] \\
\hline Jumlah Produksi & : & bal \\
\hline Estimasi Tanggal Mulai & : & \\
\hline Estimasi Tanggal Selesai & : & \\
\hline Status Pengambilan Bahan & aku : $\frac{\text { Ya } \nabla}{\text { Tidak }}$ & \\
\hline REALISASI & & \\
\hline Realisasi Tanggal Mulai & : & \\
\hline Realisasi Tanggal Selesai & : & \\
\hline Barang Kembali (Reject) & : & bal \\
\hline Kelebihan Produksi & $:$ & kilogram \\
\hline
\end{tabular}

Gambar 3. Desain Antar Muka Nota Produksi

\section{KESIMPULAN}

Berdasarkan analisis kondisi UMKM dan rancangan yang dibuat, apabila dibandingkan dengan sistem yang lama (manual) maka UMKM akan mendapatkan beberapa kemudahan karena:

- sistem yang baru dapat mencatat pesanan (identitas pemesan, jumlah, jenis dan waktu pengambilan pesanan) sekaligus melakukan pengecekan kemampuan produksi per hari

- sistem dapat menyimpan data pelanggan

- UMKM dapat melakukan perencanaan produksi yang lebih baik karena dengan sistem yang baru pemilik dapat mengetahui jadwal produksi sesuai tanggal pengambilan, mengetahui stok bahan baku dan kerupuk, melihat detail pemesan (nama, asal daerah, tanggal pemesanan, tanggal pengambilan, jenis dan jumlah kerupuk), dan jumlah kelebihan

- UMKM dapat mengetahui status pembayaran pelanggan, jika belum lunas maka UMKM dapat melihat sisa pembayaran

- Pencatatan pesanan dapat dilakukan dimana saja karena sistem dapat dijalankan pada handphone android.

\section{UCAPAN TERIMA KASIH}

Terima kasih kepada Ristek Dikti untuk dana DIPA Direktorat Jenderal Penguatan Riset dan Pengembangan, Kemenristek Dikti, Nomor SP DIPA 042.06-0/2017, tanggal 7 Desember 2016. 


\section{REFERENSI}

[1] http://bisnis.liputan6.com. 28 Februari 2016. Diunduh 15 November 2017.

[2] Wirjono, E.R., dkk. (2012). Survei Pemahaman dan Pemanfaatan Informasi Akuntansi dalam Usaha Kecil Menengah di Daerah Istimewa Yogyakarta. AUDI: Jurnal Akuntansi \& Bisnis, Vol. 7, No. 2, Juli 2012.

[3] Rifani, L., dkk. (2016). Aplikasi Sistem Informasi Akuntansi pada Usaha Kecil Menengah Kampung Kue Rungkut Surabaya. Seminar Nasional Sistem Informasi Indonesia (SESINDO).

[4] Astuti, M., dkk (2013). Peningkatan Produktivitas Usaha Kecil dan Menengah (UKM) Berbasis Technology Content untuk Mendukung Pelaksanaan Masterplan Percepatan dan Perluasan Pembangunan Ekonomi Indonesia (MP3EI) 2011-2025. Sidoarjo: Universitas Muhammadiyah Sidoarjo

[5] https://www.slideshare.net/LNK961/sistem-informasiproduksi. Diunduh 15 Oktober 2017

[6] Muslihudin, M. dan Oktafianto (2016). Analisis dan Perancangan Sistem Informasi Menggunakan Model Terstruktur dan UML. Yogyakarta: ANDI Offset. 